Before the War the Germans imported a large supply of soya beans from Manchuria. This has not been a great success, as the stocks became rancid.

Tuberculosis is a well-known index of a people's heslth and nutrition. At the end of 1941 the deathrate from tuberculosis was greatly raised in the occupied countries, and it has also risen in Germany, as in the War of 1914-18. Tuberculosis seems rife in Belgium. Generally, the increase noted in the disease is ascribed to various causes such as the breakdown of preventive measures, the return of war prisoners to France with 'open' tuberculosis, migration and under-nutrition. The number of primary infections seems to be increased and, owing to the lack of fuel, the restricted dietary is used by the body tissues of patients in sanatoria mainly for thermogenesis and energy production instead of combating tuberculous lesions.

Summer diarrhœa is again prevalent in the occupied countries.

Little accurate information can be obtained concerning epidemics, though from time to time reference is made to such outbreaks in the foreign Press. Recently it was stated that a severe epidemic of scarlet fever was raging in Denmark. In eastern Poland a virulent outbreak of tularæmia has been reported. This disease was previously unknown in Poland and seems to have been introduced from the U.S.S.R.

The chief epidemic bugbear is typhus. In Rumania there is little or no typhus, and the situation there appears to be well in hand. Polish prisoners of war, who might have conveyed the disease, were removed from the malarious area in the bend of the Danube to a healthier district, on public health grounds. Since the War, there has been much typhus in Poland, especially in the western region. In Warsaw and the Warsaw district there were some four thousand cases in 1940 as against thirty-three in 1938. There has been some typhus among German troops and in the front line. How much typhus has occurred in Germany it is impossible to say because the German figures do not include troops or residents in refugee camps. There has been no typhus in Hungary. Eighty-five cases are noted as occurring in a prison at Marseilles. The disease was imported from North Africa.

Every German soldier is inoculated with an omnibus vaccine in one administration. This contains an attenuated vaccine against typhus, an antityphoid vaccine (polyvalent) and a vaccine against dysentery. The inclusion of the latter vaccine seems of doubtful value. On the Continent a dead vaccine against typhus is chiefly used. The Germans are largely employing a brand prepared at the Pasteur Institute, Paris. There is a shortage of drugs, especially as regards anæsthetics, morphia and quinine.

The Allied Governments have announced that their first charge after the War will be to feed the inhabitants of the occupied countries, and they are making plans for this responsibility. If these countries are liberated gradually the task, obviously, will be much easier than if Germany collapses suddenly, as in 1918. A Continental expert considers that the chief de- mands will be for proteins, carbohydrates, yeast and ascorbic acid. The food should be supplied in as concentrated a form as possible in order to feed the greatest number. At first it will not be necessary to aim at an ideally balanced diet. Energy-providing foods will be the main requirement.

\section{GEOLOGY, GEOLOGISTS AND THE WAR EFFORT}

$O^{N}$ various occasions apprehension has been expressed by British geologists at the haphazard use of them and of their science in the prosecution of the War. For example, the general unawareness of the services which geologists are able to render was dealt with by Prof. P. G. H. Boswell in his presidential address to the Geological Society in 1941. Later, Prof. H. H. Read discussed the position in an article in Nature of January 10, 1942, and he has recently returned to the same topic in a talk, referred to below, to the Parliamentary and Scientifio Committee. Further, in NATURE of March 14, 1942, the role of geologists in war-time was considered in $a$ leading article, the concluding sentence of which was: "There must be more enlightened direction from above, to ensure that wherever geology impinges on human activity, in war or in peace, the contribution it can make is recognized without delay and appropriate action taken".

This advice, wherever else it may have borne fruit, appears to have fallen on stony ground, if we are to believe a Press report, at a "northern school of military engineers", where it is stated that $\mathbf{a}$ squad of water-diviners has been formed in the Royal Engineers. The information has most likely aroused nothing but a little pleasurable excitement among the general public who, as Prof. Boswell and Prof. Read both emphasized, are deplorably ignorant of geological matters. Unfortunately, however, this interesting item of British news was reproduced in the New York. Times under the caption "Dowser Squad in Army-British to use Water-Divine $\mathbf{s}$ in the Middle East". Certain of the Americans, like most of the Russians, are more aware of the part to be played by geological knowledge in war, and this small news item will not tend to increase their estimate of British military efficiency.

The present position was summed up in a revealing reply given by Sir J. Grigg in the House of Commons on January 19, in answer to a question by Capt. Studholme as to what extent the War Office rellies upon dowsers for advice on water supply. The reply is worth quoting in full: "The War Office does not rely on dowsers for advice on water supply in the United Kingdom, and so far as I know the only place where they have been tried is the Middle East. A report of their performance there showed a very small percentage of successes, and orders were issued that scientific geological methods only were to be used."

Total war implies the use of any and every means 
to beat the enemy. There are circumstances in which the employment of a squad of dowsers would be justifiable and proper to this end. Those circumstances would arise when no geologists were available or no geological information obtainable. Then in that dire hour, water-divining, witchcraft, magic or necromancy of any hue might be called upon both 'to amuse the troops' and to lend a degree of colourful camouflage to plain 'wild-catting'.

But these circumstances justifying the use of dowsers do not exist, for both geologists and geological information are in plentiful supply. It is known that a number of geologists are serying in many branches of the army, but not as geologists; among the members of the Canadian forces in Great Britain are geologists of experience, resource and skill. The staff of H.M. Geological Survey of Great Britain includes geologists completely conversant with every aspect of underground water-supply; many academic and professional geologists are available with a skill in the investigation of groundwater problems acquired in many years of consulting practice. A galaxy of geological talent is thus ready and eager to apply the resources of their science. We have, however, to record the melancholy fact that, so far as we know, two geologists are employed as such in the British Army. During the War of 1914-18, the number of geologists employed as such in the Forces was, by slow and painful_steps, raised to five; the recent formation of the 'Dowser Squad' appears to indicate that there is still little appreciation in military circles of the services geologists can perform.

It is probable that these remarks will incite the wrath of water-diviners. It must here be explained that this present protest is more concerned with the non-employment of geologists, who are demonstrably equipped for the investigation of underground water, than with the employment of water-diviners, who are not demonstrably equipped with any certain powers in this direction. In this latter connexion, it is warth while to recall the tests of dowsers made at Guildford some thirty years ago. These tests are recorded in the Sanitary Record and Municipal Engineering of May 2, 1913, and were conducted by a committee of scientific men with the late William Whitaker, F.R.S., as chairman. Whitaker had no rival in his knowledge of the groundwater of southeast England. Three sites were chosen which gave a variety of known underground water conditions. One site had $20 \mathrm{ft}$. of gravel on clay and was traversed by a large sewer, the second formed the top of $a$ service reservoir from which water was rapidly being run off, and the third was known to contain a hidden spring with a yield of about 50,000 gallons an hour. These conditions afforded an ideal test for waterdiviners. Seven diviners were conducted over the sites and their findings recorded and compared. The descriptions of these would require too much space, but the conclusions of the Committee may be given. They are as follow:

"The general conclusions of the Committee on comparing the state of facts known to exist with the indications given by the diviners, are that whatever sensitiveness to underground water may exist in certain persons, of which some evidence has been given, it is not sufficiently definite and trustworthy to be of much practical value. Moreover, the lack of agreement with each other shows that it is more a matter of personal mentality than any direct influence of the water. The diviners as a rule confine their attention to small streams of water, and as there are few places where these cannot be found they may well show a large percentage of successes."

On the most charitable judgment, therefore, the powers of water-diviners are 'not proven'; on an ordinary judgment, they are "not ... of much practical value". 'The formation of the 'Dowser Squad' of the Royal Engineers is an event which cannot commend itself to the scientific public. It is an event, too, which becomes inexplicable when it is recalled that an account of the uses of geology during the last War was published by the Royal Engineers themselves in a volume entitled "The Work of the Royal Engineers in the European War of 1914-1919 : Geological Work on the Western Front" (Chatham : Secretary, Institution of Royal Engineers, 1922).

In the talk* to the Parliamentary and Scientific Committee to which reference has been made, Prof. Read makes a number of representations, among which is one inviting that Committee to press upon the War Office and other Service Departments the importance of the contributions that geology can make to the war effort. Prof. Read quotes Sidney Paige, senior geologist in the North Atlantic Division, U.S. Engineers, as saying : "Let thought be directed toward methods of supplying all possible relevant technical data, geological and otherwise, to those who have a particular engineering job to perform in the Army or out of it".

One of the difficulties in carrying out this sound advice is that unfortunately geologists alone appear to be qualified to decide the type of work for which geology is required. This restriction results fundamentally from the neglect of geological studies in the schools and universities, a neglect which forms the subject of another of Prof. Read's representations.

This difficulty just mentioned-that geologists know best when they should be employed-is among the topics considered by F. L. Aurin in a "Memorandum to Members of the National Service Committee of the Ameriean Association of Petroleum Geologists" $\uparrow$. In this memorandum, it is pointed out that engineering skill cannot be substituted for the geologist's knowledge of rocks. Aurin maintains that this has been repeatedly demonstrated in the United States and cites the case of the present road between Los Angeles and the San Joaquin Valley; the present route was indicated as the most feasible one by geologists about fifteen years ago, but for many years competent engineers struggled with construction and maintenance problems on an alternative route. $\mathrm{He}$ asserts that geologists should have worked ahead of the construction parties on the Alaskan Highway, and that geologists should be on other critical military

- Geology and Geologists in the War and the Peace. By Prof. H. H. Read. (Parliamentary and Scientiflc Committee, Courtfleld House, London, S.W.7.)

† Bull. Amer. Assoc. Petroleum Geol., 26, No. 7 ; July 1942. 
roads such as any from India to China. Aurin's memorandum contains the following pertinent paragraphs :

"Since the type of work to which geological skill will contribute can be determined only by a geologist, it is essential that there should be an organization in the Army comparable to that used in industry. No industrialist of experience would dream of attempting to make the decision of whether or not geologic work is desirable on a given project. He, therefore, establishes a chief geologist with adequate staff to advise him when and where and what type of work should be done and to recruit the essential personnel and assign it to its tasks. There should, therefore, be such a staff geologist so located that he will automatically learn of contemplated construction projects and of the areas where knowledge of the geology will contribute to the effectiveness of attack or defense. These men will then be able to advise that a certain number of geologists with certain qualifications are needed at this, or the other point."

"Without some such mechanism as has been outlined, I see no hope that geology can be used as one of our special tools for winning the war. If such mechanism is provided, I have no doubt that it will contribute very substantially and that each geologist so employed will save men and materials for other effort and will, in special cases, contribute as only a highly trained specialist can contribute to our success."

"In this war, as in no preceding war, we depend on science, and geology is a specialized branch of science for which there is no substitute."

It appears from this memorandum that the United States, in spite of its much better geological record th' $n$ that of Great Britain in the War of 1914-18 and of its considerable awareness of the importance of geology, still has not reached perfection in these matters.

The utilization of geology and other branches of scientific knowledge was the topic of the discussion which followed Prof. Read's talk, to which notes by various speakers are appended. There, for example, Mr. J. G. Bennett, of the British Coal Utilisation Research Association, considers that the technical information already available from the coal survey of Great Britain is not being exploited to the fullest possible extent. Dr. N. F. M. Henry regards geologists as themselves largely to blame since they have neglected to take active steps to ensure that geological knowledge is properly applied. More fundamentally, Mr. G. B. R. Pimm, of the Institution of Structural Engineers, considers the utilization of science and scientific workers by the Service Departments as part of a much larger question, namely, their proper use in the War, and the reconstruction and post-war periods. Mr. Pimm considers that this "can only be brought about by Regulations introduced by Organised Science, defining the place of Science in the service of the community, and the status, and rights and duties of all scientific bodies, particularly the Chartered Bodies already charged with the advancement of the various branches of Science".

These are broad and large matters following upon the consideration of the place of dowsers in the war effort, but the mobilization of the small 'Dowser Squad' is a symptom of a widespread disease.

\section{J. J. THOMSON}

The Life of Sir J. J. Thomson, O.M., sometime Master of Trinity College, Cambridge

By Lord Rayleigh. Pp. $\mathrm{x}+300+8$ plates. (Cambridge: At the University Press, 1942.) 18s. net.

T ORD RAYLEIGH has written a most excellent 1 and satisfying account of the life of Sir Joseph Thomson. The book gives an adequate explanation of Thomson's epoch-making scientific work, and, in addition, a sympathetic and revealing description of his characteristics as a man.

Modern physical science is not an easy subject to expound to those who have no background of scientific knowledge. A choice has to be made between using elementary mathematics, and eschewing even the simplest equation in favour of a sometimes long circumlocution in words. In the preface, Lord Rayleigh makes it clear that he has chosen the latter course- "No formulæ have been used". Even so, eminent literary men have been heard to say they could not follow the scientific part of the book. Whether this is due to the difficulty of the author's task or to the deficiencies of a literary education must remain a matter of opinion.

Within the limits Lord Rayleigh lays down for himself, Thomson's work is well described, due emphasis being given to the more important results. The new physics may be said to have begun with Röntgen's discovery of the X-rays in 1895 . The rays were found to make gases conductors of electricity, and Thomson and Rutherford carried out a joint investigation which showed that conducting particles are produced by the X-rays and that the particles can be made to carry a current if acted on by an electric force. By this process the charged particles are removed, as indeed they are if the conducting gas is left to itself. Thus there are likenesses and differences between conduction through gases and through liquids; both are due to the motion of charged particles or ions, but in conducting liquids the ions are always present, while in gases they have to be formed continually by an ionizing agency. On these lines an explanation of the phenomena of conduction through gases was given.

Thomson then turned to a study of cathode raysthe straight rays which proceed from the negative electrode when a current is passed through a gas at low pressure. Two views of their nature were held : most English physicists, following an original sugges tion of Varley, thought that they consisted of a flight of negatively electrified particles, while a theory of waves was supported in Germany. The rays are deflected by a magnetic field, and, at an early date, Thomson, chiefly for this reason, took the corpuscular view. He measured the deflexion caused by a known magnetic field, and the kinetic energy of the rays by a thermo-couple, and thus found that the velocity was $15,000 \mathrm{~km}$. a second and the ratio of mass to charge was $2 \times 10^{-8} \mathrm{gm}$. per coulomb, to compare with $10^{-5}$ for the hydrogen ions in liquids, about a thousand times greater; thus in cathode rays either the charge must be larger or the mass smaller. In 1897 Thomson made the cautious statement : "these numbers seem to favour the hypothesis that the carriers of the charges are smaller than hydrogen atoms"-a momentous pronouncement which does not seem to have created much interest at the time; the chemical atom was too firmly established. Then he attacked the problem in another way. If the cathode 